\title{
From the Asian crisis to the global credit crisis: reforming the international financial architecture redux
}

\author{
Barry Eichengreen
}

Published online: 7 March 2009

(C) The Author(s) 2009. This article is published with open access at Springerlink.com

\begin{abstract}
Asian crisis and the debate over how to reform the international financial architecture but also by the outbreak of the most serious global credit crisis in generations. This paper reviews the debate over how to strengthen the international monetary and financial system in this light.
\end{abstract}

\section{Introduction}

The Asian crisis was a shock to the countries at its epicenter and more generally to the international economic and financial system. One result was a debate on how to adapt policy in emerging economies and strengthen international financial markets. Contributors to the literature on what came to be called reforming the international financial architecture quickly sorted themselves into two camps. ${ }^{1}$ The first offered proposals for radically reshaping the international system. The second, less ambitiously, emphasized the need for limited policy adaptations, mainly in emerging economies, and for even more limited changes in the structure and governance of international financial markets. In the end it was that second approach that carried the day.

The global credit crisis of 2008 places both the assumptions underpinning that earlier exercise and its achievements in a new light. The presumption, reflecting the

\footnotetext{
${ }^{1}$ Adopting the terminology used by then-Treasury Secretary Robert Rubin in a speech at the Brookings Institution almost exactly 10 years ago (Rubin 1998).
}

An earlier version of this paper was presented to a meeting of the Tokyo Club, Tokyo, Japan, 11-12 November 2008. Comments of the participants there and of the editors of this journal are acknowledged with thanks. I am grateful as well to the Tokyo Club for permission to publish this revised version. Financial support from the Coleman Fund Risk Management Research Center at the University of California, Berkeley is acknowledged with thanks.

B. Eichengreen $(\bowtie)$

Department of Economics, University of California, Berkeley, 549, Evans Hall \# 3880, Berkeley,

CA 94720-3880, USA

e-mail: eichengr@econ.berkeley.edu 
fact that the 1997-8 crisis hit emerging markets but not the U.S. or Europe, was emerging markets should emulate the advanced countries. They should build securities markets like those in the advanced countries. They should regulate their banks in the manner of the advanced countries. More generally, when determining how to reform domestic monetary and financial arrangements, they should look to the high-income world.

The 2008 crisis clearly shattered this presumption. It revealed the inadequacy of transparency in the high-income countries. It laid bare the inadequacy of supervision and regulation, failures in the coordination of macroeconomic and regulatory policies, the pervasiveness of regulatory arbitrage, and incentive problems associated with compensation practices in the financial-services industry. It dissolved any notion that prevailing practice in the high-income countries is an appropriate standard for emerging markets. But it offered little guidance as to what other standard to put in its place.

Another product of the crisis was a second round of calls for a new international financial architecture. These came from Gordon Brown, were echoed by Nicolas Sarkozy, and were embraced by George W. Bush. Here, however, calls to action were not accompanied by details. It was not clear whether leaders intended to emulate their predecessors by proposing modest changes to the prevailing architecture or whether they envisaged a more radical approach.

A new round of architecture discussions is clearly in the offing. Both to avoid reinventing the wheel and prevent, predictable mistakes it may be helpful, therefore, to understand the dynamics and limitations of the earlier exercise.

\section{Changes in the international financial architecture anticipated in 1999}

A decade ago mainstream reformers focused on strengthening supervision, regulation, financial transparency and corporate governance through the adoption of international standards and codes. Morris Goldstein had already proposed an international standard for banking supervision and regulation (Goldstein 1997). Subsequent contributions generalized this to a range of other policies and practices related to financial stability. The idea was that standards and codes would encapsulate best practice. They would offer concrete targets to which countries could aspire. Compliance would constitute a visible indicator of what had been achieved. Standards would provide a focus for market assessments of national practice and apply peer pressure insofar as laggards experienced higher borrowing costs. They would provide a focus for the surveillance activities of the International Monetary Fund and perhaps also restrain its temptation to hold developing countries to ever more demanding requirements.

Some dismissed standards as likely to be so general as to have little practical effect. Others complained that standards with bite would be rigid and prescriptive; they would end up foisting on emerging markets one-size-fits-all institutional advice. $^{2}$ Emerging markets would be instructed to dismantle bank- and family-led systems of corporate control in favor of an Anglo-Saxon system emphasizing hostile

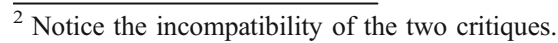


takeovers and proxy fights even when the functional prerequisites for the effectiveness of the alternative were not in place. The IMF and other official bodies charged with overseeing the new standards lacked expertise in auditing and accounting practice, bank regulation, and insolvency procedures. More generally there was skepticism that governments would feel significant pressure to upgrade prevailing practice.

To be sure, the process of negotiating the new standards was long, complex and arduous, and the results were less than ideal. To see this one need only recall that it took nearly 10 years to update the existing Basel standard for capital adequacy for internationally active banks which the recent crisis has shown to be deeply flawed. The IMF found it difficult to marshal the resources needed to assess practices in issue areas relatively far removed from the macroeconomic. It was reluctant to issue blunt statements where compliance was inadequate. Governments refused to allow it to undertake such reviews when they anticipated that the outcome would be unfavorable. ${ }^{3}$

That said, there has been progress in the promulgation of standards and codes. There are the aforementioned FSAPs organized jointly by the IMF and World Bank and introduced in May 1999. These reviews of the condition of national financial systems are undertaken with input from experts seconded from national agencies and private-sector bodies as a way of addressing the problem of limited internal resources. By-products of these assessments are Reports on the Observance of Standards and Codes (ROSCs). Reports covering 12 areas, including auditing and accounting, bank supervision, transparency, corporate governance, and insolvency and creditor rights, are produced approximately every two years. In 1996 the IMF had already targeted transparency and data dissemination by establishing the General Data Dissemination System and the Special Data Dissemination Standard for countries active on international capital markets. The SDDS lists 18 categories of data covering four sectors of the economy and sets down standards for coverage, timeliness, accuracy and public access. Participation is voluntary but highlighted by the Fund's SDDS Bulletin Board, which links to relevant national sources. There is the Basel Committee's Core Principles for Effective Banking Supervision which date from 1997. The OECD, in conjunction with the Financial Stability Forum, established principles for corporate governance in 1999. ${ }^{4}$ Official bodies have also highlighted the standards promulgated by private groups such as the International Federation of Accountants, International Accounting Standards Board and International Organization of Securities Commissions.

The question is how much difference is made by these standards and codes. Sundarajan, Marston and Basu (2001) report an effect of compliance with the Basel Core Principles on financial stability outcomes. Christofides, Mulder and Tiffin (2003) find that accounting standards, investor rights, and SDDS subscription matter for spreads and credit ratings. Cady (2004) estimates that SDDS subscription reduces

\footnotetext{
3 Thus the IMF reportedly asked the United States to undergo a Financial Sector Assessment Program (FSAP) prior to the outbreak of the subprime crisis, which the U.S. government rebuffed. The U.S. finally agreed to an FSAP at the end of 2007 (Thomas and Munchetty 2008).

${ }^{4}$ Since updated in 2004.
} 
spreads on new sovereign foreign currency bond issues by some 75 basis points. Glennerster and Shin (2007) offer a similarly upbeat assessment, arguing that subscribing to the SDSS and releasing information through publication of an Article IV review and a ROSC reduces credit spreads significantly. ${ }^{5}$ Schneider's (2005) estimates are a bit smaller, but her results are broadly consistent with those of Glennerster and Shin.

Other evidence is less reassuring. There is the flawed Basel II standard for capital adequacy, two of whose pillars are banks' internal models of value at risk and commercial credit ratings for banks lacking internal models, both of which have been shown to be insufficient for measuring risk. ${ }^{6}$ There is the OECD's standard for corporate governance, which has been shown by the crisis to be an inadequate basis for limiting principal-agent problems and risk taking in the financial sector in particular. There is the evidence of Tong (2007) and others that public information made available through the SDDS discourages investment in private information. ${ }^{7}$ Common features of these problem areas include excessive confidence in market discipline, acceptance of the premise that practice in the advanced countries is an adequate standard for other countries, and the belief that markets always process and assimilate information efficiently.

A second focus of the reform agenda was the nexus between banks, capital flows and exchange rates. In the Asian crisis countries, banks were the weak links in the financial chain. They suffered from lax internal controls, concentrated exposures, and inadequate capital buffers. Banking crises in Asia, like banking crises elsewhere, had devastating macroeconomic effects.

While there were some distinctive features of the Asian case, there were also commonalities with other regions. The capital account of the balance of payments having been at least partially opened, banks were able to fund themselves abroad, generally at short tenors in foreign currency. ${ }^{8}$ Where loans were denominated in the domestic currency, the result was a currency mismatch which could have disruptive consequences when the exchange rate moved. Even where loans were denominated in foreign currency, their tenor was longer than that of the banks' foreign liabilities, resulting in a maturity mismatch that could be equally disruptive if capital flows turned around. ${ }^{9}$ These problems were extreme in the Asian crisis countries, but they were not limited to the region.

The prevalence of these funding practices was attributed to the perception that banks were too big and politically connected to fail, which encouraged risky borrowing but also a willingness to lend on the part of foreign counterparties. Their dominance reflected long-standing use of the banking system as an instrument of

\footnotetext{
${ }^{5}$ Indicative presumably of strengthened investor confidence.

${ }^{6}$ I discuss both Basel II and the rating agencies at a greater length in Section 4 below.

${ }^{7}$ Furman and Stiglitz (1998) similarly argue that transparency standards that reduce the dispersion of beliefs across individuals may perversely amplify market volatility.

${ }^{8}$ The role of this famous double mismatch in the Asian crisis was highlighted early on by Goldstein (1998) and discussed further in Goldstein and Turner (2004).

${ }^{9}$ We now see, as a result of the credit crisis in the advanced economies, that this maturity-mismatch problem and excessive reliance on short-term (often foreign) funding is not limited to financial institutions in emerging markets.
} 
industrial policy. In other words, public-sector bailouts were the quid quo pro for the banks directed lending. In cases such as Thailand and South Korea, opening to shortterm flows prior to opening to long-term flows aggravated the problem. In others, failure to embrace greater exchange rate flexibility encouraged banks and firms to leave their currency exposures unhedged. The devastating macroeconomic consequences were similarly ascribed to a model of state-led late development that privileged banking and left bond markets underdeveloped (Greenspan 1999).

Post-crisis reform focused on this nexus. This attempted to put banks on a firmer commercial basis and limit the perception of too big to fail. In some countriesSouth Korea for example - the crisis was followed by an unprecedented wave of bank exits and takeovers. Between 1997 and early 2000 the number of Korean commercial banks had fell from 26 to 7 - an extraordinary development in a country that had never in its history experienced the closure of a major financial institution.

More broadly, however, practice lagged principle. Moody's (2007) describes the case of Indonesia, where owing to lax corporate governance banks continue to lag their regional peers in the implementation of international standards, although the standards themselves are not obviously inferior to those of neighboring countries. Fitch's indicator of the health of national banking systems as of April 2008 - that is, before the spread of the credit crisis and global slowdown to emerging markets - gave ratings of "weak" or "very weak" (D or E on an A-E scale) to almost $70 \%$ of emergingmarket banking systems. Half of all emerging-market systems are in the D category and 20\% were rated E. Only 11 received a B ("strong") rating-Bahrain, Chile, Czech Republic, Estonia, Korea, Kuwait, Mexico, Qatar, Saudi Arabia, South Africa and UAE — while only seven qualify for a C ("adequate") rating - Brazil, Latvia, Malaysia, Oman, Slovakia, Slovenia and Thailand. There is a preponderance of weak (D or E rated) systems in every emerging region other than the Gulf Cooperation Council.

More fundamentally, there was an inadequate understanding of what constituted a safe and sound banking system. Say what you will about the rating agencies, their evaluations tend to accurately reflect the prevailing consensus in official circles. Thus, the April 2008 report in question gave a rating of "strong" to South Korea's banking system, which required a massive government bailout six months later when dollar funding dried up. Even more damningly, the rating agencies did not flag serious vulnerabilities in the U.S. banking system in the first half of 2007. A common feature here was failure to grasp the risks of excessive reliance on leverage and wholesale funding. ${ }^{10}$ It was the naïve belief that privatization was enough to convince bankers that they would not be bailed out in the future like they had been in the past, where in fact private banks can be too big and connected to fail.

Another feature of the post-Asian-crisis architecture was a more measured approach to capital account liberalization. The need was acknowledged by the IMF as early as the spring of $1998 .^{11}$ A series of subsequent staff studies and policy

\footnotetext{
${ }^{10}$ There were other problems as well, of course, such as inadequate internal controls and regulatory arbitrage (shifting high-risk exposures to conduits and structured investment vehicles). But that is a subject for another paper.

${ }^{11}$ Eichengreen and Mussa et al. (1998) emphasized the need for a more measured approach. This synthesis was presented to the Executive Board in the spring of 1998, and its findings were reflected in the associated board discussion and conclusions of the chair (IMF 1998).
} 
statements reiterated the desirability of capital account convertibility as a long-run goal but emphasized preconditions for ensuring that the benefits outweighed the costs. ${ }^{12}$ They warned that capital flows could be volatile and that countries should avoid large current account deficits that heightened their dependence on foreign funding. This was advice that emerging markets in Asia and, to a somewhat lesser extent, Latin America took to heart: they shifted from current account deficit to surplus and accumulated foreign reserves as protection against sudden stops.

The efficacy of this advice is evident in the current crisis. Countries running current account surpluses, while far from immune, have avoided 1997-8 style crises, while those running current account deficits have experienced grave difficulties as funding for those deficits has dried up. Countries with ample reserves can avoid sharply contractionary adjustments. They can intervene to stabilize their banking systems insofar as foreign reserves exceed the decline in foreign finance. ${ }^{13}$

The problem is that not all countries were equally diligent at limiting capital inflows and preventing deficits from widening. In Central and Eastern Europe, countries that allowed very large external deficits to develop are now paying the price. In part this was a problem of false confidence. The Baltics and other Eastern European countries had not experienced an Asia-like crisis. They were under the misapprehension that their capital inflows were stable, either because foreign banks dominated the local market, intermediating those flows, or because their special status as EU members would reassure investors. In the event they were disappointed.

The other problem was a dearth of instruments with which to manage flows. Interest rate responses tend to be at best ineffectual, at worst perverse. ${ }^{14}$ Sterilization is costly-even for China now that domestic interest rates exceed their U.S. equivalents. Holding-period taxes can disturb investor confidence if applied with anything but the greatest delicacy. ${ }^{15}$ The only instrument guaranteed to be effective is fiscal policy. By raising public saving, governments can influence the saving/ investment balance. But doing so is difficult, especially in democratic societies where decisions regarding taxation and public spending are dominated by other priorities.

Another focus of the post-Asian-crisis agenda was limiting currency and maturity mismatches. ${ }^{16}$ This was to be achieved through strengthening supervision and regulation of the banking system and by adopting more flexible exchange rates to encourage hedging by firms and households. ${ }^{17}$ Here too progress is best described as

\footnotetext{
12 See inter alia Prasad, Rumbaugh and Wang (2005), Kose, Prasad, Rogoff and Wei (2006) and Prasad and Rajan (2008a, b).

${ }^{13}$ As in the case of Korea. The contrast is striking between Korea's response to the last crisis, when it was forced to raise interest rates in a desperate effort to re-attract flight capital, and this one, when it has been able to avoid interest rate increases and instead work to re-liquify its banking system.

${ }^{14}$ Raising interest rates to damp down the inflationary effects only tends to attract more capital inflows. Lowering rates discourages inflows but stimulates domestic demand, similarly resulting in problems of inflation and real overvaluation.

15 Recall how their imposition in Thailand in late 2006 led to a stock market crash.

${ }^{16}$ See inter alia Goldstein and Turner (2004).

${ }^{17}$ Empirical studies (e.g. Duttagupta, Fernandez, and Karasadag 2004) suggest that the shift toward more flexible exchange rates has contributed to the development of deeper and more liquid hedging markets and encouraged banks and firms to better hedge their foreign currency exposures.
} 
mixed. In Eastern Europe, regulators prevented banks from incurring currency mismatches but did not prevent them from passing them on to households and firms. In countries like Hungary the majority of home mortgages and even car loans are denominated in Swiss francs and euros. The idea that households would be cautious about incurring foreign currency liabilities because the exchange rate was floating within a band turned out to be naïve. The same can be said of the idea that a floating won would prevent Korean banks from incurring large foreign currency exposures.

In this instance the problem is not a lack of instruments but a reluctance to apply them. In some cases the need is for more vigorous regulation of the banking and financial system - no more pretending that when banks pass on their mismatches to the nonbank sector the problem has gone away. In others it means getting serious about exchange-rate flexibility so that firms and households appreciate the risks of foreign-currency obligations. Here too many governments have talked the talk but not walked the walk. The IMF's classification of de facto exchange rate regimes (Bubula and Otker-Robe 2002, as updated by the authors) confirms that there has been some movement in the direction of more flexible exchange rate regimes and away from crisis prone intermediate arrangements: the share of emerging markets with intermediate regimes was down to $41 \%$ in 2006 , from $77 \%$ in 1996 . But $41 \%$ is far from a negligible fraction. Moreover, this movement away from intermediate regimes has halted in recent years. Flexible exchange rates are no panacea, but recent experience from Estonia to Latvia suggests that regimes of limited flexibility can contribute dangerously to the build-up of vulnerabilities.

A final agenda item in the earlier round of architecture discussions was enhancing the capacity of the International Monetary Fund and allied institutions to anticipate and manage crises. As part of the effort to better anticipate risks, surveillance of national and international financial systems was strengthened. At the national level there were the aforementioned Financial Sector Assessment Programs. At the international level there was the creation in the Fund of a Capital Markets Department and biannual presentation to the board of a Global Financial Stability Report. In 2006 there was a Multilateral Consultations Initiative to bring together a handful of systemically significant members in order to better anticipate and head off cross-border risks. There was also investment in constructing forecasting models and early-warning indicators of potential crises.

These too are works in progress. The Fund's capital markets function has been hamstrung by the difficulty of competing for talent with high-flying private institutions. ${ }^{18}$ Energy has been dissipated on daily reports to management on events occurring overnight in financial markets.

The idea that the IMF should strengthen its early-warning systems is back on the table; it features prominently in Gordon Brown's proposal for reforming the global financial architecture. ${ }^{19}$ The experience of the last 10 years does not give one much confidence in the success of this enterprise. Given the speed with which financial structures change, legitimate questions can be asked about whether forecasting models based on historical data can provide reliable early warnings of impending

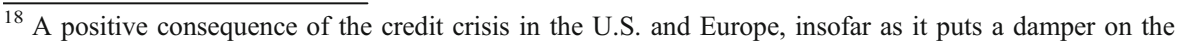
expansion of the financial-services industry, may be to relax this constraint.

${ }^{19}$ See Reuters (2008).
} 
crises. ${ }^{20}$ To be sure, there have been cases where crises could be foretold, Argentina in 2001 being an example. ${ }^{21}$ In this instance the problem for the Fund was not anticipating the crisis but flagging the need for corrective policies in a way that did not precipitate the very disruptions that it was seeking to avert. It was compelling a member, even one that depended on Washington, D.C. for financial assistance, to take corrective action. ${ }^{22}$ It was finding a way of curtailing its assistance without provoking an economic and financial meltdown. ${ }^{23}$

The intervening decade also saw proposals for the IMF to act more like a true lender of last resort (Fischer 1999). ${ }^{24}$ This idea drew inspiration from the creditorpanic interpretation of the Asian crisis (Radelet and Sachs 1998), according to which liquidity disbursed quickly in large amounts could have prevented the region's fundamentally-sound economies from succumbing to liquidity crisis. But empowering the Fund to disburse large amounts of money subject to only light conditionality was never viable; this would have put too much discretion in the hands of semianonymous technocrats who would have been the sole adjudicators of what were crises of solvency and what where crises of liquidity. The Meltzer Commission (International Financial Institution Advisory Commission 2000) proposed limiting the ability of the IMF to disburse front-loaded assistance to prequalified countries, where soundness of the banking system was the principal criterion determining prequalification.

\footnotetext{
${ }^{20}$ There is also the problem of Type 2 error - of warning of (and therefore) precipitating crises that would not otherwise occur. I am on record as questioning whether the Fund can succeed at developing effective early-warning system (Eichengreen 2002).

${ }^{21}$ Four years of economic stagnation, soaring unemployment, real overvaluation, a heavy debt load and complete lack of monetary flexibility being incontrovertible leading indicators in this particular case.

${ }^{22}$ This problem was even more acute in the case of the Multilateral Consultations Initiative, participants in which were unlikely to borrow from the Fund. Thus the first such consultation, in which the Fund brought together the United States, Japan, China, the euro area and Saudi Arabia to discuss risks to financial stability posed by global imbalances, did not suffer from shortcomings of diagnosis but did nothing to compel the participants to take corrective action.

${ }^{23}$ The decision of the IMF, with U.S. Treasury backing, to lend additional resources to Argentina as late as August 2001 is indicative of the dilemma. The Argentine episode, like the Mexican and Asian crises before it, also raised concerns that international rescues were a source of moral hazard - that multilateral "bailouts" did as much to encourage risky behavior as to address its consequences. It pointed to the need for a more orderly way of resolving crises, if only so that the IMF might, on occasion, be able to stand back and let events take their course. Suggestions here included an international bankruptcy regime, an IMF-directed sovereign debt restructuring mechanism, and the addition of collective-action clauses to sovereign debt contracts. The idea of an international bankruptcy regime went back at least to Raffer (1990) and Sachs (1995). Rogoff and Zettelmeyer (2002) summarize the intellectual history. Krueger (2001) is associated with the proposal for a Sovereign Debt Restructuring Mechanism. Proposals for promoting the adoption of collective action clauses include Macmillan (1995) and Eichengreen and Portes (1996) and were promoted by the U.S. Treasury during John Taylor's stint there. It is not surprising that schemes for a full-blown international bankruptcy court came to naught; neither creditors nor debtors were willing to trade an imperfect but workable system for the uncertainty of radical reform. Even a Sovereign Debt Restructuring Mechanism, under which only select decisions regarding debt resolution would have been made by an independent panel, under IMF aegis, proved a bridge too far. The response ultimately agreed was the more widespread use of collective action clauses by emerging markets, starting with Mexico in 2003. How much difference these contractual provisions will make is yet to be seen, the new arrangements not having been tested yet by a major emerging market crisis.
}

${ }^{24}$ An earlier call to this effect was Sachs (1995). 
The problem with this proposal, which did not go unappreciated at the time, was that banking-sector soundness was not the only or even for that matter the most important determinant of economic and financial stability; the view that it was had been heavily informed by the Asian crisis and by the priors of the members of the Meltzer Committee. There was also the danger that application might send an adverse signal about the state of a country's finances (since it would be signaling its potential need for funds), and that disqualifying a previously prequalified country (as necessary when its policies deteriorated) could precipitate the very crisis of confidence that the facility was designed to prevent. ${ }^{25}$

The idea that the Fund should be transformed into a true lender of last resort that provides unlimited liquidity without conditions is back on the table as a result of the current crisis (Sachs 2008). On October 29 ${ }^{\text {th }}, 2008$ the Fund announced the creation of a new front-loaded, quick-disbursing, essentially unconditioned lending facility (the Short-Term Liquidity Facility, or SLF) for countries with strong policies experiencing liquidity problems as a result of the credit crisis. This jettisoned the problematic focus on banking-sector stability of the Meltzer Report, replacing it with general language to the effect that qualifying countries would have to display "a good track record of sound policies." It abandoned the unworkable idea of prequalification. And it avoided the adverse signaling problem in that every country, almost regardless of its policies, has suffered from the crisis and would benefit from access to dollar liquidity.

All this said, there has hardly been a mad rush to sign up. And this was still far from a true lender-of-last-resort facility in that disbursements were limited to five times the recipient country's quota. ${ }^{26}$ There is also the danger that countries denied access to the facility because of large current account deficits or for other reasons will suffer capital flight as a result of that fact. This has led some, e.g. Dervis (2008), to suggest that access to the facility should be expanded - that additional countries should be provided with large amounts of front-loaded liquidity. Such proposals however come with an acknowledgment that liquidity support will have conditions attached. If so, we are likely, ultimately, to be back in a world where every country's eligibility for IMF assistance will have to be judged on its individual merits, with either light, heavy or no conditions attached.

A final issue in the earlier round of architecture discussions was IMF governance. Asian countries came away from their crisis believing that the Fund was inadequately responsive to their needs and excessively influenced by the United States. The threat that they might opt for a regional alternative was motivation for governance reform. ${ }^{27}$ A governance structure that enhanced the perceived legitimacy of the IMF was seen

\footnotetext{
${ }^{25}$ A watered-down facility along these lines, the Contingent Credit Line (CCL), was establish in 1999, but no country applied, and the facility was allowed to lapse in 2003. During the tenure of Rodrigo de Rato as managing director, the Fund then sought to establisher a successor facility, the Reserve Augmentation Line (RAL). Unlike some other elements of de Rato's "Medium Term Strategy" for reforming the Fund, this one died a quick death.

${ }^{26}$ The IMF itself provided no details on the size of the facility, although the Wall Street Journal (29 October 2008) referred to up to $\$ 100$ billion of three-month loans. At the time of writing, total free IMF resources are roughly $\$ 200$ billion, while five times quota for emerging markets as a group approaches $\$ 700$ billion. So it would be reassuring to address the Fund's financial-resource constraint.

27 The Japanese government had proposed an Asian Monetary Fund during the earlier crisis, but this was torpedoed by the active opposition of the United States and the reluctance of China to participate.
} 
as important for the credibility of its advice. And a more efficient governance structure was seen as necessary for streamlining its decision making.

The subsequent process focused on adjusting quotas and voting shares. Proposals for new quota formulas were tabled, starting with those of the Cooper Committee in 2000 , but there was no agreement on a formula. This is not surprising given that the quota formula has multiple functions. Quotas determine countries' financial contributions to the Fund. They determine how much they can borrow. Along with the fixed number of basic votes bestowed on every member, they determine how many votes each member is entitled to cast when strategic decisions and amendments to the Articles of Agreement are considered. They thus shape the voice that different countries have in the deliberations of the institution.

At the Bank-Fund meetings in Singapore in 2006 it was decided to push ahead with ad hoc quota increases for four under-represented emerging markets, China, South Korea, Turkey and Mexico, and to impose a two-year deadline on deliberations leading to a more comprehensive revision. ${ }^{28}$ This approach did not please countries that were not so favored such as India and Brazil. Nor did this stopgap lend legitimacy to the quota-revision process. The more comprehensive agreement was announced in early 2008 in time for the spring Bank-Fund meetings and approved by members holding the requisite $85 \%$ of votes in the Fund. It increased the number of basic votes, modestly enhancing the voice of small countries. It provided additional budget and resources to the two Executive Directors representing large numbers of African countries and therefore with especially heavy workloads. It specified a new quota formula whose arguments included a weighted average of GDP at market prices and GDP at purchasing power parity (where the latter favored poorer countries) as well as measures of the level and variability of a country's international transactions.

But the new quota formula is no more analytically defensible than its predecessors. ${ }^{29}$ In addition the changes in quota shares resulting from application of the formula are too small to change anything consequential. The voting shares of Germany and Italy decline from pre-Singapore levels by a miniscule 0.16 and $0.08 \%$ of total votes, respectively. China's increase is $0.88 \%$. India and Brazil receive increases of 0.42 and $0.30 \%$. Mexico receives an increase of $0.27 \%$. It is hard to see how such marginal changes will substantially affect decision making, more so insofar as most operational decisions are reached in the Executive Board on the basis of consensus, not votes.

\footnotetext{
${ }^{28}$ The United States agreed not to seek or accept an increase in its quota as part of that subsequent revision. One reason for the failure to adopt the quota-reform proposals of the Cooper Committee had been that almost any formula placing a significant weight on GDP at market exchange rates would have represented an increase in U.S. representation and a reduction in that of developing countries.

${ }^{29}$ It is hard to mount a coherent defense of the use of GDP at purchasing power parity. The IMF exists to lend to and represent the interests of countries according to their weight in the international system. What matters from this point of view is the market value of their transactions, which points to the use of market exchange rates; purchasing power parity adjustments are designed to facilitate international comparisons of living standards, not the market value of transactions. The use of purchasing power parity weights thus smacks of political expediency. And the fact that further ad hoc adjustments were applied, overriding mechanical implementation of the quota formula, before submitting the agreement to a vote does not enhance the legitimacy of the process. These changes were designed to prevent the voting shares of the high income countries as a group from rising further and those of low income countries from falling.
} 
Thus, emerging markets continue to feel that they lack adequate voice and representation in the IMF. The result is that the Fund lacks legitimacy. This is evident in the reluctance of emerging markets to seek the assistance of the institution. Pakistan went first to its neighbor China for assistance. Hungary resorted initially to the European Central Bank (despite not being a member of the euro area) rather than appealing to the Fund.

\section{Changes in the international financial architecture not anticipated in 1999}

Ten years on is also an appropriate time to note changes in the international financial architecture that were not anticipated during the earlier debate. Examples already have been noted: these include the tendency for capital to flow "uphill" from developing to developed economies, the accumulation of reserves, and the emergence of sovereign wealth funds. ${ }^{30}$

These unanticipated developments are all aspects of the same phenomenon. The shift from current account deficit to surplus in the developing world reflects a decision by governments and central banks, in the wake of disruptive crises, to run their economies under less pressure of demand. ${ }^{31}$ The result was a decline in investment relative to saving in emerging East Asia in particular (Rajan 2006, Asian Development Bank 2007). Sustaining those surpluses meant limiting currency appreciation, in turn implying intervention and reserve accumulation. To the extent that reserves also constituted a firewall protecting the economy from financial volatility, this was part and parcel of reducing the risk of financial instability. With the Federal Reserve doing all in its power to propel the U.S. economy out of its 2000-1 recession and the U.S. more generally adopting an attitude of benign neglect toward its current account, the result was uphill flows of capital and global imbalances on a scale not witnessed previously. ${ }^{32}$

Nor was the emergence of sovereign wealth funds unrelated. ${ }^{33}$ With their accumulation of foreign assets it was inevitable that emerging markets would seek to

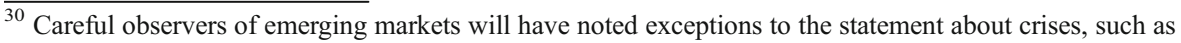
the banking crisis in the Dominican Republic in 2003, currency crashes in Indonesia and Thailand in 2005 and 2006, and a number of debt restructurings. But these were exceptions to the rule, and none had systemic significance or matched Asia in 1998 for its intensity.

${ }^{31}$ And thereby to reduce the risk of financial instability.

${ }^{32}$ Chronic U.S. deficits were, in fact, nothing new, but their scale has been unprecedented in recent years. And, previously, with developing countries importing capital, finance for the U.S. deficit had come primarily from other advanced economies.

33 The rapid growth and rising prominence of these funds was certainly not something that was widely anticipated in the late 1990s. In contrast, there was already widespread awareness of the emergence of the other so-called "new power brokers" (to quote the McKinsey 2007 survey of the same name), namely hedge funds and other highly-leveraged institutional investors. One strand of the architecture debate emphasized the need to regulate hedge funds and limit the threat they posed to financial stability (De Brouwer 2001). My own view (Eichengreen and Mathieson et al. 1998) was the footloose and chameleonlike character of hedge funds made them exceptionally difficult to regulate; I am not surprised that the last 10 years has seen little progress in this direction. Moreover, it has always been my view that there is nothing fundamentally different between hedge funds and other highly-leveraged investors, including investment banks and broker-dealers. It is tempting to see the subprime crisis, which has seen both hedge funds and investment banks (like Bear Stearns) fail as a result of having engaged in many of the same practices, as validation of this point.
} 
diversify their holdings, not just across countries and currencies but to include equity as well as debt. Deciding on equity stakes was not an appropriate task for central bank portfolio managers; it was logically delegated to self-standing sovereign wealth funds and outsourced to private investment advisors.

These funds have been the subject of codes of conduct and standards for transparency to reassure the countries that were the targets of their investment that strictly commercial, as opposed to political, criteria would prevail. ${ }^{34}$ But it is not clear that we should be concerned that sovereign funds will in fact be used to advance political agendas rather than simply to diversify the government's foreign investment portfolio. What is clear is that this problem would not have arisen but for the dedication of emerging markets to the maintenance of current account surpluses and undervalued exchange rates and the willingness of the United States to entertain large deficits. Having depended on emerging markets to finance its current account deficits, it is more than a bit disingenuous for the United States to now object to its lenders' desire to hold assets other than depreciating U.S. debt securities.

How many of these changes in the international financial architecture should be regarded as permanent, and how many are likely to be passing phases? The debate over Bretton Woods II is precisely a debate over whether this particular constellation is likely to endure or whether it might come to an early and abrupt end. ${ }^{35}$ The most compelling argument for the Bretton Woods II proposition that the current constellation of exchange rates and imbalances could endure indefinitely was that the U.S. had a comparative advantage in producing financial assets while emerging markets had a comparative advantage in producing manufactures (Caballero et al. 2006). Emerging markets lacked the technology to reliably develop and issue securitized claims in the volume demanded by their investors; they solved this problem by running current account surpluses and importing securities from the United States.

This rationale is more than a little suspect in the wake of U.S. credit crisis; it is now described as "they sell us toxic toys and we sell them toxic securities." The crisis has cast doubt on the ability of the United States to supply high quality financial assets to the rest of the world. As the U.S. economy lurches into recession and foreign purchases of its financial securities decline, global imbalances show clear signs of unwinding. And if the U.S. deficit shrinks, so too will the surpluses of other countries, as a matter of definition. By implication, their accumulation of foreign reserves will slow. Indeed, the heyday of sovereign wealth funds may already be over, as countries from South Korea to the United Arab Emirates draw on their reserves to stabilize their exchange rates and recapitalize their banking systems.

\footnotetext{
34 The IMF has become the main vehicle for negotiation of a code of conduct for sovereign funds- not without pushback from the governments operating those funds. In February 2008 the European Commission indicated that it would craft its own code for sovereign wealth funds active in Europe. In May the U.S. Treasury bilaterally negotiated an agreement on a list of basic principles for sovereign wealth fund conduct with Singapore and Abu Dhabi.

${ }^{35}$ Bretton Woods II is the name given to the thesis of Dooley, Folkerts-Landau and Garber (2003) that the constellation of global imbalances was an equilibrium phenomenon that was indefinitely sustainable. It is not to be confused with calls for a new Bretton Woods from the likes of Gordon Brown (see above). Of course, there is an irony in the fact that both camps employ the same terminology.
} 


\section{Systemic issues}

The rating agencies are targets of criticism in every crisis if only because they are bearers of bad news and their pronouncements inevitably make a bad situation worse. But the criticisms levied against them in Asia in 1998 now resonate more strongly in Europe and the United States. Ratings are lagging rather than leading indicators. The rating agencies persist in issuing upgrades even after a market or economy shows clear signs of problems. They then issue downgrades only after conditions have deteriorated. This positive-feedback behavior amplified volatility in Asia in 1997-8, and it similarly amplified volatility during the subprime crisis. We see this again in the failure of the rating agencies to recognize the vulnerability of countries with large current account deficits.

In part this problem reflects the inability of the agencies' models to forecast out of sample. They are estimated on short time series. Just as the agencies rated emergingmarket debt in the 1990s on the basis of only a few years of data on the operation of sovereign bond markets, they rated subprime-mortgage-backed securities using only the short time series generated by an enormous housing boom. ${ }^{36}$ Their best forecasters are continually hired away by the banks, which pay higher salaries. Then there is the conflict of interest between the agencies' advising and rating roles. Asked by an issuer of collateralized debt obligations how to structure an instrument so as to obtain an AAA rating, it can be impossible for the agencies to rate the resulting issue any other way. ${ }^{37}$

One way of addressing this conflict would be to bar agencies issuing ratings from also advising issuers. But it is not clear how to do this without at the same time creating other problems. ${ }^{38}$ The major rating agencies currently earn fees from advising issuers on how to structure their securities but not from issuing ratings, which are public information. One small U.S. rating agency, Egan-Jones, earns income by providing its ratings only to paying clients. The problem with more widespread adoption of this model is that public information would become private. Companies would have to charge for their ratings. The information provided by the latter would then be less freely available. It is not clear that ratings could be used by regulators whose operations require a certain degree of transparency.

Another approach would be to levy a tax on every security issuer and/or trader and use the revenues to compensate those issuing the ratings, which could then

\footnotetext{
${ }^{36}$ In addition there is the problem that the model is estimated on a different structure from the one that currently prevails in the market. In the case of housing-related securities, the agencies adopted a methodology long used to model and rate corporate bonds, which are subject to a very different set of risks. Emerging market corporations that were subject to the so-called sovereign ceiling (where their ratings could not exceed those obtained by the sovereign) complained of similar practices.

${ }^{37}$ There do not appear to be such widespread complaints by investors that the rating agencies, which also consult with governments, that pay to have their bonds rated, have conflicts of interest in the sovereignrating context. Why not is an interesting question.

${ }^{38}$ New York State Attorney General Andrew Cuomo has pressed the rating agencies to agree to a fee structure in which they charge for services all through the issuance process to prevent issuers from shopping for ratings. Securities and Exchange Commission head Christopher Cox, for his part, has proposed a bar on allowing the same employee from both advising the issuer and rating his security. But whether assigning these two functions to the occupants of neighboring cubicles would really make much of a difference is unclear.
} 
remain public. But it is not obvious how such a scheme could be administered. What private rating companies would qualify for redistribution? What public or semipublic entity would decide on their shares? Would non-U.S. issuers and investors be subject to the tax? Would it have to be levied and administered on a global basis? Just posing these questions casts doubt on the viability of such schemes. ${ }^{39}$

Alternatively it has been suggested that agencies providing advice on how to structure an issue could be required to keep skin in the game. They could be required to hold a certain amount of the same security in their own portfolios to ameliorate potential conflicts of interest between the financial-and investment-advisor functions. But where the application of such regulation to a commercial bank or even investment bank would be straightforward, how to apply it to rating agencies would be less so. ${ }^{40}$ It would require a fundamental transformation of the function of those agencies from modestly capitalized advisors to generously capitalized financial institutions.

Another approach would be to encourage competition. If investors and issuers had more rating agencies to turn to, those that repeatedly got it wrong would lose market share and ultimately franchise. Promoting competition is first and foremost a problem in the United States, where Moody's, Standard \& Poor's and Fitch dominate the market. This reflects the need for a rating agency to secure Nationally Recognized Statistical Rating Organization (NRSRO) status in order to be a viable competitor. NRSRO status allows fiduciaries who pick a bond that goes bad to defend themselves against legal or regulatory sanction: they can say "an NRSRO recognized by the SEC told us these securities were good." Agencies without this status have an extra handicap when competing for business. ${ }^{41}$

The Credit Agency Reform Act of 2006 is intended to increase competition by making it easier to obtain preferred status from SEC staff. So far this has led to the granting of NRSRO status to exactly one additional rating agency, the abovementioned Egan-Jones, in December 2007. ${ }^{42}$ It may also be possible to address the problem by encouraging more rating agencies in other countries. There has been movement in this direction: following the 1997-8 crisis a number of Asian countries promoted the establishment of local rating agencies. There is now an Association of Credit Rating Agencies in Asia with 25 members at last report.

The question is why these entities have not taken more market share from the Big Three. It could be that economies of scale and scope dominate the advantages of local knowledge. But, if so, it is not clear that more competition is a feasible solution to the inefficiency of the rating process.

\footnotetext{
$\overline{39}$ Again, shades of the Tobin tax.

${ }^{40}$ Even for commercial and investment banks, the efficacy of this reform, advocated in Europe, can be questioned. In fact many investment banks held large numbers of the securities they originated on their own balance sheets, whether for warehousing or proprietary trading purposes. They ended up suffering serious credit losses as a result, but this did not deter them from originating highly risky securities.

${ }^{41}$ Dizard (2008) observes that prior to the granting of NRSRO status in the 1970s there was a greater tendency for investors to shop around for the most accurate rating - since there was no anointed rating agency that guaranteed them protection from legal and regulatory action-and in this earlier world there was a greater incentive for rating agencies to derive their fee income from investor rather than issuers.

${ }^{42}$ After 11 years of trying by the company's principals.
} 
These observations are more troubling insofar as credit ratings are used to gauge the riskiness of assets under the Basel II capital accord for banks that do not possess internal models through which value at risk can be estimated. ${ }^{43}$ Insofar as ratings are an unreliable measure of the riskiness of an asset class, they provide unreliable guidance on the size of the capital buffer needed to guard against price fluctuations. They also accentuate the procyclicality of the financial system. Insofar as ratings rise (fall) in expansions (contractions), they reduce (increase) the capital that banks must hold against their existing assets, allowing for the further procyclical expansion (contraction) of the balance sheet.

Similar criticisms can be registered about the use of internal models of value at risk as a basis for assessing the adequacy of capital buffers under Basel II. These models chronically underestimate the likelihood of extreme events. Like the rating agencies' models, the banks' models were developed in a period of low volatility. Given encouragement from management to minimize costs, staff estimating and running these models feel pressure to underestimate risks so as to avoid inflating capital requirements. The operation of these models also accentuates the procyclicality of credit. During expansions, highly-leveraged issuers perform relatively well; their debts are therefore modeled as less risky, allowing banks to reduce their capital buffers and lend more; the inverse then occurs during contractions.

Besides the fact that capital requirements are too low and procyclical, there is the fundamental problem that they do not apply to the so-called shadow banking system. The idea that banks should be required to hold a minimum level of capital flowed from the observation that they were subject to runs (which liquid capital helped them to pay out) and that in extremis they should be the recipients of last resort lending (where requiring them to hold capital was one way of preventing them from taking additional risk in response to the associated moral hazard). The problem now is that nonbanks are similarly exposed to the danger of a run, through the money market rather than from depositors, and they are similarly too important to be allowed to fail.

These problems are easier to point to than to solve. Abolishing capital requirements and instead requiring banks to issue subordinated debt places more faith in the power of market discipline than most of us would feel comfortable with in the wake of the recent crisis. Going back to Basel I, where different assets were placed into different risk buckets carrying different amounts of required capital, would throw away valuable information about value at risk conveyed by the correlation between asset classes which provided much of the impetus for moving to Basel II. Abandoning risk weighting entirely and basing capital requirements on unweighted assets, as some have suggested, would be equally bad.

My own suggestion would run as follows. ${ }^{44}$ Start by clamping down on regulatory arbitrage. The fundamental reason for the rise of conduits and structured investment vehicles was to evade capital requirements. Like banks, these entities funded themselves short term, by issuing asset-backed commercial paper or securing a revolving credit line from the parent, while making illiquid investments. But because their operations were off the bank's balance sheet, capital did not have to be

\footnotetext{
${ }^{43}$ For more on these internal models see below.

${ }^{44}$ Laid out in more detail in Eichengreen (2008).
} 
held against those investments. Often, however, those investments came with a guarantee that the parent or the issuing bank would take them back if the market in them collapsed. Even where this was not the case, the fact that these subsidiaries were related to the parent often meant that it was too embarrassing to allow them to fail. Unavoidably, then, these off-balance sheet operations came back onto the banks' balance sheets at the worst possible time. For these reasons, the logic for requiring capital to be held against these operations is overwhelming. The experience of Spain, where regulators have already done so, demonstrates its feasibility.

Next, build in some redundancy. In the spirit of the U.S. Alternative Minimum Tax it should be possible to compute a bank's minimum required capital in a couple of different ways and hold it to the higher value. One would be the Basel II value that requires a bank to consolidate its portfolio (effectively, to move its off-balancesheet exposures back onto its balance sheet) and calibrate the associated capital requirement using its internal model or commercial credit ratings. Another would be a simplified Basel I value, that requires the bank to simply hold capital that equals some fixed fraction of its portfolio. The old Basel I procedure could be simplified by eliminating the old process of risk weighting. ${ }^{45}$

Then raise the minimum capital ratio under this old "Basel I pillar" to more than $8 \%$. There are compelling reasons to require banks to hold more capital. The risk of extreme events, against which capital is supposed to provide a cushion, is clearly greater than regulators and bank risk officers had convinced themselves. More capital will mean more own funds at risk, which will encourage more prudent behavior. More capital will of course also mean higher intermediation costs. But intermediation costs have fallen significantly in recent years as a result of financial innovation. ${ }^{46}$ Accepting slightly higher costs in return for significantly greater stability would not be an undesirable tradeoff.

Finally, index the capital ratio to the rate of change of bank balance sheets. ${ }^{47}$ When balance sheets are expanding, the capital ratio-as opposed to the simple amount of capital that banks must hold - should increase. This would restrain the rate of growth of bank lending in good times and, conversely, limit the contraction needed to build capital in bad times. The tendency for the present system of capital requirements to accentuate procyclical financial dynamics would thereby be attenuated.

\section{Implications for debate}

What inheritances will be handed down from the first (post-1997) round of architecture discussions to the new debate over how to reform the international financial architecture that will follow the 2008 credit crisis? The 2008 crisis reinforces arguments for enhancing the transparency of financial instruments and

\footnotetext{
${ }_{45}$ The Swiss National Bank has recently proposed something along these lines for banks under its regulatory jurisdiction.

${ }^{46}$ Not least the types of securitization that are also at the root of the present crisis.

${ }^{47}$ As argued by Goodhart and Presaud (2008).
} 
markets. The opacity of collateralized debt obligations and the ease with which banks disguised exposures by moving them off balance sheet were significant factors in the crisis. At the same time, that experience underscores doubts that transparency in and of itself will be enough to prevent excesses and ensure that market discipline is applied before serious vulnerabilities are allowed to build up. The idea that wellinformed investors, supported by adequate transparency standards, will be able to discipline large institutional investors and thereby prevent significant vulnerabilities from building up has shown to be naive. Insofar the problem is not just the availability of information but also the capacity of investors to process it (even sophisticated institutional investors appear to have been unable to fully assimilate the available information about the risk characteristics of complex instruments), transparency alone is not enough. ${ }^{48}$

In addition there is the need for strengthened supervision and regulation-another inheritance from the earlier architecture debate that will be a higher priority in light of recent events. There will be discussion of regulations limiting investment in complex derivative securities to sophisticated investors (as recommended by the Corrigan Committee). ${ }^{49}$ There will be reforms of Basel II to require internationally active banks to hold more capital, to key their capital to the riskiness of not just their investments but also their funding, and to make capital requirements less procyclical, as described above. There will be reform of the credit-rating industry. All these are issues that featured to some extent in the earlier architecture literature that will again be priorities in future discussions.

One issue that did not feature in the earlier architecture debate but which will surely be the subject of extensive discussion this time is the desirability of forcing transactions in credit default swaps and other derivative instruments into clearinghouses and an organized exchange. ${ }^{50}$ Counterparty risk was not a prominent factor in the Asian crisis. ${ }^{51}$ But it is central to why the failure of Lehman Brothers ramified into a systemic crisis in 1998. When one large financial firm was unable to execute its obligations, several of its counterparties quickly found themselves in the same position. In turn, the problems of each of these counterparties created a problem for several of their respective counterparties, and ultimately the whole house of cards tumbled down. This problem can be ameliorated by reorganizing the market in credit default swaps and similar instruments so that transactions are netted through a central clearinghouse or traded on an exchange with real-time gross settlement.

Such reforms will be resisted by broker-dealers who earn commissions on overthe-counter transactions. There will also be resistance on the grounds that exchangebased trading will require the standardization of instruments. It will limit scope for tailor contracts to individual circumstances. But the political leverage of large financial institutions has been diminished by the crisis. And greater standardization is an acceptable price to pay for financial stability.

\footnotetext{
$\overline{{ }^{48} \text { But then most contributors to }}$ the earlier architecture debate never suggested that transparency was a sufficient condition for financial stability.

49 See Counterparty Risk Management Group III (2008).

${ }^{50}$ An early and influential statement of the case is Cecchetti (2007).

${ }^{51}$ Although it did figure in the failure of Long-Term Capital Management that followed in 1998.
} 
There also be more discussion of the need for a global financial regulator or "World Financial Authority" along the lines suggested by Eatwell and Taylor (2000). Questions will be raised about the appropriateness of delegating the supervision and regulation of financial markets to individual countries, given the extent to which problems in one country can infect others. In cases like Switzerland, where shortterm bank liabilities are two-and-a-half times GNP, questions will extend to the notion that the national authorities are the appropriate entity to deal with rescue and recapitalization operations. No doubt the IMF, the BIS and the Financial Stability Forum will all scramble to lay claim to the mantle of World Financial Authority.

But if the first round of architecture discussions teaches us one thing, it is that countries are reluctant to compromise their sovereignty. They will be reluctant to delegate the regulation of national financial institutions and markets to any supranational authority. Notwithstanding the creation of the Asian Bond Fund and Asian Bond Market Initiative, there was no willingness to do so in Asia. EU member states have been reluctant to embrace the case for a single financial regulator for their single market. It would not be surprising if the current wave of enthusiasm for a World Financial Authority dies down as soon as the worst of the crisis has passed.

This is not to deny that there will be renewed efforts to strengthen, harmonize and coordinate supervision and regulation through the Basel Committee of Bank Supervisors and the Financial Stability Forum. Europe being the only part of the world with experience in creating supranational institutions, it may rethink its reluctance to move in the direction of a single regulator for the euro area or the EU as a whole. ${ }^{52}$ If one wishes to imagine more far-reaching scenarios, the least implausible is the creation of a new international body or empowerment of an existing one to issue directives for how national markets should be regulated, which would then be enacted into law by individual countries (much in manner that the European Commission's directives are enacted by EU member states). ${ }^{53}$ This could be made an obligation of countries joining the "World Financial Organization" in the same way that legislation providing freedom of access to foreign suppliers is an obligation of members of the World Trade Organization. Countries that did not adopt the relevant legislation would then see their banks denied access to foreign markets and financial instruments issued on their markets denied eligibility for the portfolios of foreign pension funds, insurance companies and the like.

Another focus of the next round of discussions, like their predecessors, will be IMF reform. This is implicit in the fact that many of those calling for a new international financial architecture refer to the need for a new Bretton Woods Agreement, the original Bretton Woods Conference being where the IMF was established. The IMF's inability to say anything critical about its large members is a weakness in the architecture. The Fund was notable for its silence when the U.S. Treasury rolled out a flawed bank rescue plan in September 2008 that emphasized purchases of troubled assets at something resembling market prices rather than capital injections - this despite the fact that the Fund had extensive experience with the resolution of banking crises and had published definitive analyses of the issue (Laeven and Valencia 2008). The inadequate voice and representation of emerging

\footnotetext{
52 Although, as we know from long experience, institutional evolution in Europe doesn't occur quickly.

53 Something along these lines has been suggested by Phillips (2008).
} 
markets, which renders them reluctant to approach the organization until it is too late, creates unnecessary vulnerabilities. The inability of the Fund to move quickly in response to unfolding events is a significant liability.

Meaningful reform requires changing the composition of the Management and Executive Board responsible for priorities and policies. A 24 member Executive Board is unwieldy; national central banks typically make decisions in a considerably smaller board. ${ }^{54}$ Corporations rely for oversight on a board of directors with considerably fewer than 24 members and an even smaller executive committee. The current board is also unrepresentative. That there are as many as nine European Executive Directors (depending on whether or not Spain is in the chair of its mainly Latin American constituency) is an anachronistic inheritance from the mid- $20^{\text {th }}$ century when decolonialization had not run its course. ${ }^{55}$ Finally, the current board is poorly structured, with regional neighbors scattered between different constituencies, former imperial powers and their one-time colonies grouped together in constituencies, and other countries assembled into groupings whose composition simply defies logic.

An appropriate response would be to downsize the board to streamline decision making, to change its composition to better reflect the realities of the $21^{\text {st }}$ century, and to rationalize the constituency system. Doing so will hinge on the willingness of the European Union to consolidate its representation (initially almost certainty into two seats, one for the euro area and one for the remaining EU countries). Consolidated European representation has been on the agenda for some time. It has been advocated by both officials (Bini-Smaghi 2004) and academics (Ahearn and Eichengreen 2007). It is now being pushed by the European Commission (EC 2008) in the face of resistance from EU member states that anticipate losing their position at the board table. ${ }^{56}$

Meaningful governance reform also requires changing a leadership selection process that allows the Europeans to nominate the managing director and the U.S. to select his first deputy. ${ }^{57}$ This anachronism reflects the era long past when the Americans and Europeans could take global leadership for granted. It diminishes the legitimacy of the institution. Other regions have increasingly objected to this convention, but with the Europeans and Americans supporting one another in the Bank and the Fund it is hard to overcome their blocking coalition. Because there is little scope for candidates to compete on their merits, there is little assurance that the most qualified will be selected. Reform of leadership selection has been on the agenda for some time (Kahler 2001), but there has been little progress. Each time the managing directorship opens up, there is a promise to open up the process a bit "the next time around." Here the failure of the United States to open up the selection

\footnotetext{
${ }^{54}$ The ECB is an exception, but with the expansion of the euro area it too plans to move to a rotation system to limit board size.

${ }^{55}$ Included in this encompassing list is Switzerland, which is not an EU member (relevant for the discussion below).

${ }^{56}$ Not all European states; some such as the Dutch have come out cautiously for consolidated representation.

${ }^{57}$ And the U.S. to designate the president of the World Bank.
} 
of the World Bank president so as to pressure the Europeans to offer the same concession at the Fund was an opportunity missed.

There are in addition far-reaching schemes for reforming IMF governance, such as making directors independent in the manner of a central bank board (DeGregorio et al. 1999) or turning over their central responsibilities to nonresident directorsthat is, to finance ministry and central bank deputies who would travel to headquarters periodically (King 2006). There has been a tendency to dismiss these ideas as unrealistic. Now that there is a new appreciation of the need for the Fund to be able to tell hard truths about even its largest shareholders, perhaps these ideas will come back on the table.

Finally, it is important to emphasize that, calls for a "new Bretton Woods" notwithstanding, the result of future discussions is not likely to be a new global system of fixed exchange rates. There have been some peculiar suggestions that the breakdown of the Bretton Woods System is the ultimate cause of the 2008 credit crisis, the implication being that the world should now go back to fixed rates. ${ }^{58}$ In fact the opposite implication follows. Had emerging markets maintained more flexible dollar exchange rates for the last five years, global imbalances, notably between the United States and the emerging world, would not have been allowed to balloon to the same extent. Less foreign finance for the U.S. deficit would have meant less accommodating U.S. financial conditions, moderating the credit boom in the United States. ${ }^{59}$ Calls for a new Bretton Woods Conference to strengthen the regulation of global financial markets are welcome. But the idea that this might translate into a new Bretton Woods System of pegged exchange rates is not.

Open Access This article is distributed under the terms of the Creative Commons Attribution Noncommercial License which permits any noncommercial use, distribution, and reproduction in any medium, provided the original author(s) and source are credited.

\section{References}

Ahearn A, Eichengreen B (2007) Europe's External Monetary and Financial Relations Since the Euro: A Review and Proposal. In: Sapir A (ed) Fragmented power: Europe and the global economy. Bruegel, Brussels

Asian Development Report (2007) Asian development report 2007. Asian Development Bank, Manila Bini-Smaghi L (2004) A Single European Seat in the IMF? J common mark stud 42:229-348

Bubula, Andrea and Inci Otker-Robe (2002), "The Evolution of Exchange Rate Regimes since 1990: Evidence from De Facto Policies," IMF Working Paper no.02/155

Caballero, Ricardo, Pierre-Olivier Gourinchas and Emmanuel Farhi (2006), “Am Equilibrium Model of ‘Global Imbalances' and Low Interest Rates,’NBER Working Paper no.11996

\footnotetext{
58 Thus, an article in the Economist (2008) argues that President Nixon's decision to close the gold window and allow the dollar to float ushered in a period of generalized floating that permitted the removal of controls on international capital flows, which in turn created current vulnerabilities. In fact the reality is exactly the opposite: it was the progressive recovery of international capital mobility following the Great Depression and World War II that ultimately undermined the viability of the pegged-but-adjustable rates of Bretton Woods.

59 Thus Warnock and Warnock (2006) estimate that foreign inflows reduced the level of interest rates in the United States by as much as 100 basis points.
} 
Cady, John (2004), "Does SDDS Subscription Reduce Borrowing Costs for Emerging Market Economies?" IMF Working Paper WP/04/58

Cecchetti, Stephen (2007), "A better way to organise securities markets," Financial Times

Christofides, Charas, Christian Mulder and Andrew Tiffin (2003), "The Link Between Adherence to International Standards of Good Practice, Foreign Exchange Spreads and Ratings, "IMF Working Paper WP/03/74

Counterparty Risk Management Group III (2008) Containing systemic risk: The road to reform. CRMG, New York

De Brouwer G (2001) Hedge Funds and Emerging Markets. Cambridge University Press, Cambridge

De Gregorio J, Eichengreen B, Ito T, Wyplosz C (1999) An independent and accountable IMF. CEPR, London

Dervis K (2008) Fairness to Emerging Markets, Washington Post, www.washingtonpost.com

Dizard J (2008) Time to Rate the Rating Agencies. Financial Times, www.ft.com

Dooley M, Folkerts-Landau D, Garber P (2003) An Essay on the revived Bretton woods system. NBER Working Paper no. 9971

Duttagupta R, Fernandez G, Karasadag C (2004) From fixed to float: operational aspects of moving toward exchange rate flexibility. IMF Working Paper no. 04/126

Eatwell J, Taylor L (2000) Global finance at risk. Polity, New York

Economist (2008) Link by link: a short history of modern finance. Economist 18:75-78

Eichengreen B (2002) Financial crises and what to do about them. Oxford University Press, New York

Eichengreen B (2008) Thirteen questions on the subprime crisis, unpublished manuscript. University of California, Berkeley

Eichengreen B, Mathieson D et al. (1998) Hedge funds and financial stability. Occasional Paper no. 166, Washington, D.C.: IMF

Eichengreen B, Mussa M et al. (1998) Capital account liberalization: Theoretical and practical aspects. IMF Occasional Paper no. 172, Washington, D.C.: IMF

Eichengreen B, Portes R (1996) Crisis? What Crisis? Orderly Workouts for Sovereign Debtors. CEPR, London

Fischer S (1999) On the Need an International Lender of Last Resort. Revised text of a paper prepared for delivery at the joint luncheon of the American Economic Association and American Finance Association, New York

Furman J, Stiglitz J (1998) Economic crises: Evidence and insights from East Asia. Brookings Papers on Economic Activity 2:1-135

Glennerster R, Shin Y (2007) Does transparency pay. IMF Staff Papers 55:183-209

Goldstein M (1997) The Case for an International Banking Standard. Policy Analyses in International Economics no. 47, Washington, D.C.: Institute for International Economics

Goldstein M (1998) The Asian financial crisis. Institute for International Economics, Washington, D.C

Goldstein M, Turner P (2004) Controlling currency mismatches in emerging markets. Institute for International Economics, Washington, D.C

Goodhart C, Presaud A (2008) How to avoid the next crash. Financial Times, p.14.

Greenspan A (1999) "Do Efficient Financial Markets Mitigate Financial Crises?” Speech at the 1999 Financial Markets Conference of the Federal Reserve Bank of Atlanta, Sea Island, Georgia

International Financial Institution Advisory Commission (2000) Report. U.S. Government Printing Office, Washington, D.C

International Monetary Fund (1998) Annual report. IMF, Washington, D.C

Kahler M (2001) Leadership selection in the major multilaterals. Institute for International Economics, Washington, D.C

King M (2006) "Reform of the International Monetary Fund," speech to the Indian Council for Research on International Economic Relations, Delhi, 20 February, www.bankofengland.co.uk

Kose MA, Prasad E, Rogoff K, Wei S (2006) "Financial Globalization: A Reappraisal," IMF Working Paper 06/189

Krueger A (2001) "International Financial Architecture for 2002: A new Approach to Sovereign Debt Restructuring," Address given at the National Economists' Club Annual Members' Dinner, American Enterprise Institute, Washington, D.C., 26 November. Available at www.imf.org/external

Laeven L, Valencia F (2008) "World systematic banking crises: A New data base," IMF Working Paper no.08/224

Macmillan R (1995) The next sovereign debt crisis. Stanford Journal of International Law 31:305358

McKinsey \& Company (2007) The new power brokers: How oil, Asia, hedge funds and private equity are shaping global capital markets. McKinsey and Company, New York 
Moody’s (2007) “Asia’s Banks-10 Years Since the Crisis,” Moody’s Banking Special Comment, Hong Kong: Moody's Investors Service

Phillips R (2008) “A Second Bretton Woods," The Globalist, www.theglobalist.com

Prasad E, Rajan R (2008a) A pragmatic approach to capital account liberalization. J econ perspect 23:149172

Prasad E, Rumbaugh T, Wang Q (2005) "Putting the cart before the Horse: Capital account liberalization and exchange rate flexibility in China", Policy Discussion Paper 05/1, . Washington, D.C, IMF

Prasad E, Rajan R (2008) A Pragmatic Approach to Capital Account Liberalization. J econ perspect

Radelet S, Sachs J (1998) The East Asian financial crisis: diagnosis, remedies, prospects. Brookings Papers on Economic Activity 1:1-74

Raffer K (1990) Applying chapter 9 insolvency to international debts: an economically efficient solution with a human face. World Development 18:301-311

Rajan R (2006) "Perspectives on Global Imbalances," Remarks at the Global Financial Imbalances Conference, London, 23 January. Available at www.imf.org/external

Reuters (2008) Brown speech on international financial reform. uk.reuters.com

Rogoff K, Zettelmeyer J (2002) Bankruptcy Procedures for Sovereigns: A History of Ideas, 1976-2001. IMF Staff Papers 49:470-507

Rubin R (1998) Strengthening the architecture of the international financial system. Treasury News

Sachs J (1995) "Do We Need an International Lender of Last Resort?" Frank D. Graham Lecture at Princeton University, Vol. 8, 20 April. Available at www.ksg.harvard.edu/cid

Sachs J (2008) “Amid the Rubble of Global Finance, a Blueprint for Bretton Woods II," Guardian OnLine (22 October), www.guardianonline.co.uk

Schneider B (2005) Do global standards and codes prevent financial crises? New York: United Nations

Sundarajan V, Thomas D, Basu R (2001) "Financial System Standards and Financial Stability: The Case of the Basel Core Principles," IMF Working Paper no. WP/01/62

Thomas C, Munchetty N (2008) "Former IMF Chief de Rato Says Global Credit Crisis Nearing End," www.bloomberg.com

Tong H (2007) Disclosure standards and market efficiency: evidence from analysts' forecasts. J int econ 72:222-241

Warnock F, Warnock V (2006), "International Capital Flows and U.S. Interest Rates," International Finance Discussion Paper no. 860, International Finance Division, Board of Governors of the Federal Reserve System 